\title{
How Relevant is the 'Terror Frame' for Discussing Media Coverage of Iraq in 2013? A Preliminary Study
} Martin Hirst*

Centre for Citizenship \& Globalization, School of Communication \& Creative Arts, Deakin University, Burwood campus, Australia

\begin{abstract}
This paper is a preliminary study of the terror frame as it is applied to media coverage of Iraq 10 years after the 2003 American-led intervention that toppled Saddam Hussein.
\end{abstract}

\section{Introduction}

This paper updates the author's previous work in this area [1-5] and briefly examines the period around the March $201310^{\text {th }}$ 'anniversary' of the 2003 invasion of Iraq as an occasion on which to reassess the viability of the terror frame as a critical lens for examining media coverage of Iraq today. One finding of the is that in 2012 coverage of Iraq in the mainstream Western media was only around 20 per cent of what it was in 2003. The diminished range of coverage, which has dropped dramatically since mid-2007, means that today Iraq is rarely on the front page or at the head of the broadcast bulletin. However, when it does make the paper, bulletin or website, news from Iraq still appears to be predominantly framed within a discourse about 'terrorism', but with one key difference: the targets of terrorist attacks in Iraq in 2013 are not coalition forces or Westerners. This has implications for how audiences in nations allied to the 'Coalition of the Willing'-who share some responsibility for the 'rebuilding' of Iraq-might relate to the rebuilding process. Perhaps unfortunately, the lessons of Iraq are more likely to be cited in relation to the ongoing 'war on terror' [6] rather than in how to conduct reconstruction of Iraq's war-damaged infrastructure, nationhood and national psyche.

\section{The history of the "terror frame"}

Since George Bush senior's first Iraq incursion in 1991, many news events from the Middle East have been framed using the ideological construction of a looming and ever-present existential threat to the lifestyles and ideals of 'the West'. This 'threat' is characterized as an almost disembodied entity 'terrorism'; a seemingly irrational and unpredictable, if not 'insane' ideology that is beyond explanation and control [7,2-5]. In the context of the Middle East and South Asia, the terror frame is also infused with a latent Orientalism that privileges a Western discourse about these regions of the globe [8]. The terror frame is not limited to post-1991 conflicts. British PM Margaret Thatcher famously invoked the 'oxygen of publicity' argument to deny the IRA airtime on British television in the late 1970s and early 1980s. However, over the past two decades, framing global conflicts in terms of 'good' versus 'evil' and describing enemies as 'terrorist', or as supportive of 'terrorism', has remained an essential ideological tool for Western governments keen to build and shore up support for shaky and dubious military alliances and interventions across the globe. Even today, more than a decade after ' $9 / 11$ ' the terror frame is still invoked and linked to the now discredited 'clash of civilizations' thesis: Since $9 / 11$, it has sometimes seemed as if the world has become consumed by battles with Islamist terrorists. From Iraq to Afghanistan, via Mali and Algeria, commentators have long argued that we are witness to a clash of civilizations [9].

\section{News frames}

The idea of news frames is an accepted theoretical construct and series of linked methods in media and communications scholarship, particularly in the study of news and journalism. Frames are devices used by reporters and editors to make sense of information and to manufacture news out of the chaos of information flows. Framing helps news workers to decide how a story is to be shaped and presented; to make decisions about which sources will be included and also to determine what issues will be fore grounded within a news story [10]. The frame of the story has two functions, which can be metaphorically described as a frame that supports like a scaffold and as a frame that sets the boundaries for inclusion and exclusion [11]. Frames can have an episodic or thematic focus. Episodic frames relate to specific events, actors or locations of problems or issues in the news. Thematic frames discuss issues within a general or more abstract context [12]. To be effective frames require narrative fidelity-they must accord with the life experiences of the reader or viewer-and empirical credibility. This means that even if there is no direct correspondence between the frame and the reader/viewer, the frame retains its usefulness because it coincides with the already mediated experience of the viewer/reader. In this sense, a frame is rendered more powerful through repeated use and audiences attach more credibility to a frame through repeated exposure. Frames can also resonate with cultural norms, which can have the effect of placing them above further empirical scrutiny and rendering them ideological in a way that seems to be common sense or taken-for-granted.

\section{Terror frame-background}

Since 11 September 2001 when more than 3000 people were killed in a large-scale attack on New York and Washington DC, it has become commonplace to talk about terrorism as being one of the biggest news stories on the globe. It has been so now for over a decade. From the moment commercial jetliners exploded into the twin towers of the

*Corresponding author: Martin Hirst, Associate Professor, Centre for Citizenship \& Globalization, School of Communication \& Creative Arts, Deakin University, Burwood campus, Australia, Tel: +61-400-975-256; E-mail: martin.hirst@deakin.edu.au

Received September 26, 2013; Accepted November 20, 2013; Published November 26, 2013

Citation: Hirst M (2013) How Relevant is the 'Terror Frame' for Discussing Media Coverage of Iraq in 2013? A Preliminary Study. J Mass Communicat Journalism 4 168. doi:10.4172/2165-7912.1000168

Copyright: (c) 2013 Hirst M. This is an open-access article distributed under the terms of the Creative Commons Attribution License, which permits unrestricted use, distribution, and reproduction in any medium, provided the original author and source are credited. 
World Trade Center and the Pentagon, the world was changed forever. Journalism was also changed by these tragic events and the continuing aftermath-seemingly endless conflicts in Afghanistan and Iraq; more terror attacks in Bali, London, Madrid, and many other cities; and massive policing operations in Australia and around the world to catch the alleged masterminds and terrorist cells-means that journalism continues to change.

The framing of the news agenda around the fear of terror and terrorism is not new: it has been around since the late 1960s. The difference today is that its manifestation has global implications as well as ethical consequences for national news organizations and journalists in all media. George Gerbner's review of the literature suggests that the terror frame was common in the late 1970s and that it goes in and out of 'fashion' depending on the issues. We can reference this easily by mentioning Northern Ireland, Latin and Central America, parts of Africa, the Middle East, South and Southeast Asia. What is common to each episode of 'terrorism' in the media, that Gerbner describes from the late twentieth century, is an ideological picture of the 'terrorist' as 'unpredictable and irrational, if not insane', and as symbolizing 'a menace that rational and humane means cannot reach or control' [7]. Writing in 1992, just after the first American-led Gulf War-that pitched George Bush Snr against Saddam Hussein after Iraq's invasion of Kuwait-George Gerbner wrote:

Bombarding viewers with violent images of a mean and dangerous world remains, in the last analysis, an instrument of intimidation and terror.. [and is] an integral part of a market-dominated system of global cultural commercialism ... Only a new international movement dedicated to democratic media reform can do justice to the challenge of violence and terror in and by the media [7]. George Gerbner's critique appears to be apt for the last decade of the twentieth century and the first decade of this century. The terror frame became the dominant media perspective for reporting 'military' and 'political' news in the first months after $9 / 11$ and then again as the invasion of Iraq grew closer throughout 2002 and into early $2003[4,5]$.

The 'terror frame' represents the new ideological sphere of limited controversy $[13,14]$, which allows very little room for an alternative perspective; the dominant view is one colored by an American perspective of 'empire. It is also 'enthusiastically' taken up by much of the Western mainstream media [15]. To 'hate' terrorists is just 'common sense'. The current 'terror frame' first gained currency during and after the first Gulf War in 1991. It grew again immediately following 11 September 2001, when it was very neatly grafted onto current American policy towards the Middle East. The 'terror frame' reached Australia on the night of the Sari Club bombing in October 2002. By March 2003 the 'terror frame' was firmly in place, and it was sufficiently accepted and powerful enough to convince a handful of governments to back the US invasion of Iraq in March 2003. The terror frame builds on the idea that the terrorists want to tear down 'freedoms' of Western society and culture-how ever ill-defined and poorly implemented those freedoms might be. On the other hand, politicians are worried that giving too much coverage to so-called terrorists might either give their cause legitimacy or dull the public mind to the supposed threat they pose. Therefore politicians and journalists are caught in the dialectic between press freedom and the need to curtail freedoms to stop terrorism $[16,17]$. This is a dangerous bind for reporters: Where do you draw the line between freedom and security? How much freedom are we willing to give up? Do we actually have to forgo civil liberties to stop 'terrorism'? Writing on the Freedom Forum website, Paul McMasters argues that government restrictions on media freedoms, in the name of combating terrorism, amount to a 'war on journalism' [18]. A key element of the terror frame is a related construct-that of the 'national interest'- which corrals the news media into a tight corner. This is an important element of the ongoing debate about defining terrorism; the frame most readily accepted is one that portrays Islam as the problem and terrorists as largely Islamic in outlook and violent in intent [19]. In the eyes of Western reporters, support for 'our' troops becomes the litmus test of patriotism and provides a cover for governments to demand largely uncritical coverage from the mainstream news media. This is one of the key ideological fault lines in the ethical worldview and practice of many journalists $[2,3,20]$. The quid pro quo (or the other side of the national interest coin) is the argument that some sovereign national systems have become 'failed states' that cannot control either restive populations or terrorist cells that seem to spring up like mushrooms in fertile soil. Thus the terror frame, when combined with national interest and linked to so-called 'failed' regimes, invites domestic audiences to align themselves with 'their' (non-failing) government for the protection of the 'homeland'.

This overview describes what was the dominant framing of the Iraq conflict of 2003. It was rehearsed in the aftermath of the September 11, 2001, attacks on the Pentagon and the World Trade Centre ('9/11') and extended in the years immediately after by further ' $9 / 11$ '-style attacks in Bali (October 2002); Madrid (March 2004); London (July 2005); Mumbai (2008) and most recently in Algeria in January 2013.

At the launch of the Iraq intervention in March 2003, the threat 'terrorism' posed to 'our' way of life had become the dominant framing device for global news, particularly news about little-known, and even less understood, small scale wars in northern Africa, Pakistan, Thailand, the Philippines and the Middle East. The Palestine-Israeli conflict was framed as a fight for Israel's survival as the lone democracy in the region surrounded by hostile and failing states that were providing safe havens for terrorists, including elements of the Palestinian leadership around Hamas and Hezzbollah. The stone-throwing youths who fuelled the 'Intifada' in occupied Palestine were portrayed almost universally as dupes of the rising tide of Islamist fundamentalism fuelled by Iran, Syria and Iraq. On this framing, there is 'terrorism'-the actions of non-State and rogue State actors (largely outside the West's sphere of influence) and 'counter-terrorism'-'military action (including the use of air strikes, psy-ops, rendition and waterboarding) conducted by elected governments'. There is a clear ideological and political bias in this practice of defining and framing terrorism as an "Us" [Western] and "Them" [Islamic] issue. The 'definitional power' of the Western states-themselves engaged in imperialist actions in the Middle East and other parts of the world-is aided by the naturalising effect of a 'range of institutions', most notably the mass media [15].

\section{Methods}

This paper is developed from an ongoing interest in how terrorism and the 'war on terror' has shaped news coverage of Iraq and other parts of the Middle East, south and southeast Asia and northern Africa since the events of 11 September 2001. This ideological device distorts the truth about conflict and does not present news audiences with a clear and true picture. Instead, the focus is on 'one, highly visible, form of terrorism' that takes on 'an iconic, fetishized and, most significantly, a highly optical character, cited in Freedman \& Thussu [19]. The less publicized but equally terrorist campaign of political and sectarian violence that dominates news from Iraq in 2012 and 2013 is not framed in the same way. The violence is not mediated through the terror frame 
because the victims are not Western civilians, but ordinary Iraqis caught in a civil conflict fuelled by corruption and religious sectarianism.

For the purpose of this analysis it was decided to collect newspaper samples that explicitly linked 'Iraq' with 'terror' 'terrorist' or 'terrorism' in the lead/opening paragraph of the news item. Thus, any news item (news story, feature, analysis or editorial) that employed the terror frame would usually flag this in the headline, or in its lead paragraph. By also including 'Iraq' as a necessary keyword in the lead paragraph the explicit link between that country and the terror frame can be measured. This method allowed me to capture all instances of keywords "Iraq" and "terrorism" without double counting entries. Hence in the tables, there are columns for the appearance of "terror" in the lead paragraph and also in subsequent paragraphs, but not in the lead. This would tend to indicate that terrorism is a concern of the story, but not necessarily the major concern, or framing device for the whole article.

This is a sound method for analyzing the framing of the item because according to journalistic conventions, the headline and/or the lead paragraph should make explicit the purpose and editorial 'tone' of the news article as a whole. A second pass of the data was made using "terror" as a keyword from the body of the article. This was done so that all references to terrorism linked with the keyword Iraq would be captured. To provide an overview of the news media's linkage of coverage of Iraq to the terror frame over the decade 20032012 a preliminary newspaper database search was carried out for each year, using various combinations of keywords that captured stories in which Iraq and terror-related keywords were used in either the lead paragraphs or in the body of the article. The keywords "Iraq" and "terror" were used to capture "terror", "terrorism" and "terrorist". The parameters of the study were extended backwards to 1998 in order to examine the pre-2003 baseline from which the rise in coverage from 2001 onwards could be measured. The second part of the study involved a closer examination of the first four months of 2013 using the same keyword searches and a study of the period February-April 2013 , in which the most attention was paid to the to 10 year anniversary of the March 2003 Iraq intervention.

\section{Data and Discussion}

After the 2013 tenth 'anniversary' of the Iraq intervention/invasion of March 2003, I undertook a preliminary study of the data comparing the combined usage of "Iraq" and "terror" in the lead paragraph in an item in several newspapers between 1998 and 2012. This revealed an interesting pattern that revealeda 'balloon' shape of the overall coverage. There is very little coverage of Iaq and terrorism before 2001, at which time it expands rapidly, like a balloon being inflated. This swelling continues for a period of two-three years-coinciding with most intense periods of fighting. The fall-off is sharp after 2004; before tapering slowly away. However, the coverage does not return to its very low pre-2001 levels. A key point here is to note the discrepancy in the volume of coverage between The Guardian and all the other papers; secondly the very low number of stories in the major Australian dailies across the period of study is also noteworthy.

Detail analysis of "Iraq" and "terror" in lead paragraphs across five newspapers 1998-2012] suggests that the terror frame is being used less frequently today than during the most intense periods of Iraq coverage in some of the world's leading newspapers. Terrorism was no longer a lead story in Iraq coverage after 2004. However, the total coverage of Iraq is broader than this as a more detailed analysis shows, there is preliminary evidence to suggest that the terror frame has taken on a steady role as the second or third lead that adds detail and background to the coverage. This preliminary study provides detail for only three newspapers and so is no more than indicative of an issue that needs further exploration. The three papers were The Age, published in Melbourne; The Australian, published nationally in Australia and The Guardian, published in the UK.

This series of figures shows that all three newspapers continue to take an interest in how terrorism and Iraq are still connected within the coverage and that the average number of 'mentions' of "Iraq" and "terror" in the same story remains well above 25 per cent across these papers for most of the past decade.

This data is interesting and provides several leads for new inquiries; including for example a more qualitative study of key dates and sequences of coverage around the siege and clearing of Fallujah city; the events following Seymour Hersh's great exposure of the horrors and crimes of Abu Ghraib and other milestone events through to the withdrawal of the bulk of US and allied fighting forces in 2010-2011.

The most striking feature of the aggregated data from the keyword searches shows that as the total volume of coverage of Iraq grew from a low base, to peak between 2003 to 2007, the percentage of coverage framed around terrorism also grew and remained at approximately one-third of all stories. The second generalised point is that after 2007 , there is a dramatic decline in the total volume of Iraq coverage. These trends were consistent across all the mastheads examined in this preliminary study.

\section{Key points in the framing timeline 2003-2010}

Within the scope of this preliminary study, little attention has been paid to a detailed analysis of the news discourse. The initial analysis of keywords in the leading (framing) paragraphs of each item shows a clear trend in the 'shape' of the coverage from 2001 to 2010.

Each paper under analysis follows this 'balloon' pattern in coverage. There is a rapid expansion of coverage from 2001-2002, which, for obvious reasons, peaks during the most intense months of fighting in 2003-2004. Several other framing devices, linked to but not identical to the terror frame are also apparent. One key frame is the idea that Iraq was a failed state under Saddam Hussein-the evidence being his alleged, but never proven links to al Qaiada-and the Western intervention was justified on that ground.

\section{Failed State/Stay the course}

Within months of the March 2003 invasion of Iraq, growing public disquiet over the crumbling justification that Iraq was helping al Qaiada and had extensive stockpiles of WMD (both of which claims were blatant lies) led to the creation of a propagandadiscourse that we can describe as 'stay the course'. The genesis of this framing technique was US Deputy Defence Secretary Paul Wolfowitz' reluctant admission in July 2003 that no WMD had been found in Iraq since the overthrow of the Hussein regime.

No such weapons have been found and little concrete evidence has been presented of an al-Qa'ida link. 'The nature of terrorism is that intelligence about terrorism is murky," Mr Wolfowitz, one of the architects of the Iraq war, said on the Fox News Sunday program.

"I think the lesson of 9/11 is that if you're not prepared to act on the basis of murky intelligence, then you're going to have to act after the fact, and after the fact now means after horrendous things have happened to this country."

Mr Wolfowitz's remarks will be seen as continuing to prepare 
Americans for the possibility that weapons of mass destruction might never be found in Iraq. (Correspondents in Washington \&Baghdad, 2003)

In September 2003, 'stay the course' was endorsed by The Australian newspaper, which had been a key outlet for the pro-invasion lobby in Australia. In an editorial headlined "Staying the course in Iraq", the paper's leader writer opined:

The US will not, cannot, cut and run. To abandon Iraq now would not only be an act of monstrous cowardice-it would demonstrate to every bandit chief in the world that while the Americans are invincible on the battlefield, they do not have the commitment to win the peace. ("Staying the course in Iraq," 2003)

Over the following years the 'stay the course' discourse and framing device grew in importance due to rising public disillusionment with progress towards a peaceful solution in Iraq. The discourse of Western forces remaining in Iraq for the foreseeable future-which I'm describing as 'Stay the course', is also linked to the frame of Iraq as a 'failed State'. The fact that it was not failing prior to Western intervention, is conveniently disregarded. This frame peaked in 2004, at around the same time that the WMD excuse for the 2003 invasion was unravelling.

Former Spanish prime minister Jose Maria Aznar raised 'stay the course' during a 2007 visit to Australia.

Speaking in Sydney last night, Mr Aznar, who led Spain from 1996 to 2004, said that the Western world was at the crossroads, and that to concede defeat in Iraq would have "very serious consequences" for global democracy [21].

Aznar's government lost an election in and the centre-left coalition that won the vote immediately withdrew Spanish troops from Iraq. A decision that Mr Aznar described as a 'mistake'. The framing of this discourse in Aznar's speech is interesting and worth examining. He explicitly links the threat of terrorism to an existential crisis in Western society and accuses opponents of the Iraq intervention of being "morally confused". "The future of the Western world depends on its ability to successfully counter the threat of terrorism." But he acknowledged that the war was unpopular, and that the threat of global terrorism had divided the West. "I think the West is going through a serious crisis; an existential one, possibly," he said.

"Our society is morally confused, strategically divided and politically weakened," he said referring to the battle between the supporters and opponents of the Iraq war [21].

In Australia, the government of conservative Prime Minister John Howard, who had been prime minister at the time of the $9 / 11$ attacks and a close ally of George W Bush, was a strong supporter of the 'stay the course' frame:

John Howard has strongly backed a continued troop presence in Iraq, warning of a huge victory for terrorism should a withdrawal by coalition forces be seen as a defeat..."We believe that ... if the coalition were to pull out of Iraq in circumstances perceived as defeat, then that would be very destabilising for the region. It would be a huge victory for the terrorists and it would be against Australia's national interests" [Mr Howard said] [22].

'Failed state', 'stay the course' and the threat of existential terrorism created a powerful triumvirate of ideological frames that fuelled public support for the war in Iraq from 2003 to 2007-08. However, another aspect of the terror frame that also helped underpin the actions of the coalition governments was the looming threat of terrorism 'at home'.

Terror frame moves to 'homegrown' jihadists

Between 2003 and 2010 the 'war on terror' was used to frame global news, particularly from the Middle East, south Asia (mainly Pakistan) and South East Asia (particularly the Philippines, southern Thailand and Indonesia).

In Australia, the UK, the United States and western Europe, the 'war on terror' also morphed into a domestic news frame. In July 2007 Australians were warned of possible threats from 'Western-born extremists in search of new targets'. A senior Australian counterterrorism official issued the warning at the Australian Security Industry Association's 2007 conference:

MrKaldas said he was not aware of any Australians currently fighting in Iraq. However, he said at least one Australian man had been stopped at the Iraq border and sent home.

MrKaldas said the conflict in Iraq had become a modern day "terror university" just as the Soviet war in Afghanistan from 1979 to 1989 had helped shape the skills and philosophies of Osama bin Laden and his cohorts.

This meant it was impossible to isolate Australia from the Middle East: "We can forget saying that what happens over there doesn't affect us here [23].

This warning from NSW deputy police commissioner carried weight and was reinforced by another expert:

Last month international terrorism expert RohanGunaratna told The Australian that a fresh crop of homegrown jihadis had been groomed to step up and replace the leaders of Australian terror cells who had been arrested or jailed.

Dr. Gunaratna said homegrown terrorists were the biggest security threat to Australia and said as much as 80 per cent of the nation's counter-terrorism resources were being dedicated to monitoring them [23].

Three men faced a British court in 2008 over a lot to detonate a suicide car bomb at Glasgow airport [24]. In 2013 another incident of domestic terrorism in the UK-an attack on a soldier leaving his barracks-reinforced the 'homegrown' threat. In Australia a longrunning court case involving a group of alleged terrorist plotters was finally resolved in 2009 with the conviction of several men over firearms and explosives caches [25]. The group at the centre of the 2009 trial formed a large part of Martin Chulov's book Australian Jihad that was suppressed in 2006. While the names of the men involved were changed in Chulov's book they are easily identifiable from published news reports at the time of their arrest. Since the events of the so-called Arab Spring, particularly the collapse of Syria into civil war, the focus has shifted to young men travelling from Western nations to fight alongside the Islamist elements of the Syrian opposition. However, the attempt to link these 'jihad tourists' to domestic terror threats in their home countries has not abated $[26,27]$.

Framing a deadly anniversary: The terror frame in 2013

My secondary interest in the preliminary study was to examine the coverage of Iraq during the so-called celebration of ten years since 2003. This anniversary in March 2013 was covered in the news media, but perhaps without the depth and detail we might have expected for 
such an important event. The notable finding from this section of the study is that, some newspapers chose not to give the anniversary much coverage. However, there was a brief spike in coverage in the first four months of 2013, which is consistent with heightened news interest in the anniversary. Once again coverage in The Guardian was greater (516 articles published on Iraq between January and April); The Australian published 115 articles and The Age, 116.

It is worth mentioning that several key figures in the 2003 invasion, were still attempting to justify their actions 10 years later, including George Rumsfeldt, Tony Blair and John Howard. A second theme was that inside Iraq itself, the occasion was marked by a spike in sectarian violence.

The framing of the event-as a moment of sadness and reflectionwas in stark contrast to the pro-war and relatively 'gung-ho' enthusiasm that greeted the launch of the 2003 attacks. The editorial feeling about the 10th anniversary is summed up in the lead to this editorial published in The Age newspaper:

When future generations look back on the invasion of Iraq in 2003, and examine the legacy of Western military intervention in Afghanistan since 2001, the test of success must be whether these nations evolved into functioning states that respect human rights, liberty and justice [28].

The editorial then explicitly links Iraq, Afghanistan and terrorism in the second paragraph:

Despite the implementation of fledgling democratic processes in each country, terrorists still find safe haven in these lands.

In the third paragraph, the terrorist 'threat' is shifted from Iraq to Iran, but it remains a constant.

This terrorism, however, is no longer sponsored by the state-and that is a big difference from what was occurring in 2003. Iraq's threat to Israel has been reduced, though not neutralized. Iran, however, has flourished in that period to become an unpredictable risk.

The 'lessons' drawn from this by The Age's leader writer is that despite the mistakes in Iraq-the false premise for the invasionterrorism remains an existential threat to 'global security', but also that military action must be a last, not a first resort in such situations. This position was also adopted by The Australian, but in much more blunt terms:

The world is better off without Saddam Hussein

The world is unquestionably a better and safer place for the toppling of Saddam Hussein. The US-led invasion of Iraq, launched 10 years ago, was the beginning of his end...It was a war that had to be fought [29].

The headline, 'A new Iraq, 10 years later', is also within the frame that regime change in Iraq was a positive move and that in this 'new' Iraq things are better than they were before March 2003. It implies that Iraq is no longer a failed state and that the rhetoric of "stay the course" was justified.

In a second editorial in The Age on the same issue a month later, the legacy of Iraq was linked to the Boston marathon bombing. In this leader, the sadness expressed earlier over the failure of the Iraq intervention is brushed aside in favor of a reminder that terrorism remains a global threat:

More than a decade after US president George W. Bush declared "war" on terrorism; we have cause to ask if the world is a safer place. In the past week, powerful bombs have been detonated in public placeskilling many people, injuring hundreds more, crippling communities and causing fear and, yes, terror, on a grand scale.

Despite mass invasions by Allied forces against the Taliban in Afghanistan or against Saddam Hussein's regime in Iraq, and despite our best efforts to guard against terrorism, evil acts still occur where and when we least expect them. The problem has always known who the enemy is and where it might strike [30].

This neatly brings together several key themes that operate within the terror frame and that have been noted in this paper-terrorism is 'evil'; we are still not safe and sometimes terrorists are 'home grown'. The headline for this editorial also encapsulates the main political and ideological point of the terror frame, it is 'a war without end'.

The situation today

Is Nouri al-Maliki becoming Iraq 's next dictator and, if he is, does anyone in Washington care? [31]

This editorial from The Guardian, seems to sum up an attitude of weary resignation that Iraq today is not necessarily a better place than it was before the Western intervention of 2003. A decade on from the Iraq war and the situation on-the-groundis vastly different; perhaps as we might expect it to be. Most foreign troops are gone and Iraqi security forces are in charge. The government of Noural-Maliki is becoming closer to Iran and is supporting the Assad regime in Syria as the ShiaSunni split widens in the Islamic world. The Guardian's editorial ends with a further reference to the terror frame:

It should therefore come as no surprise that al-Qaida, which was decimated when Sunni tribal chiefs turned against it, is back in business. Maliki's quest for domination could drive his country back into civil war [31].

The problems may not be what they were 10 years ago, but Iraq remains a central concern of US, NATO, British, Australian and general Western foreign policy. Notably, the Guardian is less sanguine than either The Age, or The Australian in its prognosis for a recovered Iraq.

The security situation on the ground in Iraq is said to be greatly improved from the height of the civil war/sectarian violence of 20062007. That may be so, but September 2012 was the deadliest month in more than two years according to Iraqi official statistics. According to Western reports it is now 'insurgents' who are responsible for the escalation in violence [32]. However, reading deeper into James Hider's report for The Times indicates that sectarian violence (Sunni v. Shia) is probably the root cause and that any link to al-Qaeda is inferential, rather than proven. The violence is linked to inter-sect rivalry between al-Maliki and his deputy Tariq al-Hashemi.

The Shia-dominated Government of Nouri al-Maliki, the Prime Minister, had accused Hashemi of having a hand in 150 bombings and assassinations, most of which were allegedly carried out by his bodyguards [32].

Hashemi was forced to flee Iraq just days after the US troop withdrawal in December 2011. Even the pro al-Maliki outlet The Times had to report that this development was unsettling:

The move has exacerbated fears that the Shia Prime Minister, Nouri al-Maliki, may use the country's UStrained security forces to silence 
political opponents. As well as serving as Prime Minister, Mr al-Maliki controls the interior and defence ministries [32].

The prevalence of sectarian violence and the threat of civil war is a major difference between 2003 and 2013. Further, in 2012-13 the body count is reported by the Iraqi government and includes civilian casualties. Unlike an earlier time in the conflict wean one American general famously said that civilian deaths were not being counted.

However the spin placed on body count figures can be misleading as the Iraq Body Count Project (which has continued for more than a decade) says June 2012 was the most violent. The IBC also claims that the civilian death toll was up in 2012 for the first time in a number of years.

The framing of the Iraq conflict—and Iraq as a 'failed state'-in 2012 is confirmed by an editorial in The Age which cites a series of issues that point to the dominant frame being that Iraq is still a failing state. The Iraq situation is also explicitly linked to Afghanistan:

Iraq's fate since foreign forces withdrew after nearly nine years of war is a grim pointer to Afghanistan's prospects...relentless sectarian conflict has killed 3100 civilians this year...Politically, too, Iraq is a mess [33].

\section{Is the terror frame still relevant to Iraq coverage in 2013?}

For this preliminary study articles were collected for the period 1 January to 30 April 2013 and analyzed using the same keyword methods as in the first tranche (1998-2012). In each case the linking of Iraq and terrorism was consistent with the previous study: Iraq and terror* were linked in all papers, though not always explicitly in the lead paragraph. In The Australian 64 per cent of articles in the survey period linked Iraq and terrorism; in The Age it was 26 per cent and in The Guardian, 24 percent.

However, the lack of explicit framing (within the lead paragraph) does not indicate that the 'terror frame' is no longer being applied. The new front in the 'war on terror' is northern Africa. A number of violent incidents in Algeria and continuing conflict in Mali and other north African nations are evidence that the global conflict is on-going.

With the end of the Algerian crisis, a new phase in the War on Terror starts. Having fought to crush al-Qa'ida and its adherents in Iraq and Afghanistan, Western leaders are now pledging to confront them in the vast and lawless wastes of northern Africa...Many jihadist groups with al-Qa'ida links operate in that vast area...The revolutions of the Arab Spring were seen as a rebuff to al-Qa'ida's violent ideology but, in a perverse way, they have helped the jihadists. The regimes of Egypt, Libya and Tunisia suppressed Islamic extremism. Their downfall has led to a collapse of border controls and a lawlessness in which the militants thrive.

The jihadists' rise in the Sahel threatens to destabilise governments, send a new wave of terrorists to Europe and create huge numbers of refugees. They also threaten Western energy supplies [34].

It is interesting to note that in this long extract from Martin Fletcher's 'analysis', first published in The Times and reprinted soon after in The Australian, that the Arab Spring is mentioned as being helpful to 'the jihadists' by creating a series of failed or failing states in Egypt, Libya, Syria and Tunisia. This destabilisation-from a Western perspective-is seen to be a precursor to perhaps more terrorist activity.

The trope of things would have been worse today if we had not invaded Iraq shows how useful the terror frame has been and continues to be for ruling elites in the West to justify ongoing interventions across the Middle East and, in more recent times, into North Africa as well. It became common in 2012, as the civil war in Syria continued in a bloody stalemate, to suggest that foreign fighters-many of them alleged 'jihadists' - were fighting on the anti-government side. Sources for this information were not always identified, but claims from Syrian president Bashar al-Assad were often mentioned.

Jihadist groups in Syria represent less than $10 \%$ of all fighters. Still, many have combat experience in Iraq, Afghanistan, Yemen, and Libya and compete for funds and weapons with the Free Syrian Army, the main armed opposition group. "Most foreign fighters go abroad to defend their fellow Muslim brethren from being slaughtered. Portions of foreign fighters are not fighting to help establish a future state for Syrian nationals," commented Aaron Y Zelin. "Rather, they hope to annex it to be part of their grander aims of establishing emirates that will eventually lead to a re-established Caliphate, however fanciful this project might be."

In this piece the source of the quote is named as 'Aaron Y Zelin', but not further identifying features are given.Zelin is a researcher at the Washington Institute for Near East Policy, which according to Source Watch [35], is funded by the American Israel Public Affairs Committee as a pro-Israeli lobby group.

\section{Conclusion: 'Pilgrims killed in blast'}

BAGHDAD-Attackers killed at least 32 pilgrims in Iraq on Thursday, the police said, in what appeared to be a spate of sectarianmotivated violence as the country continued to struggle with a political crisis in its fractured government [36].

This incident, which appears to be a terror-style attack on civilians and clearly linked to Shia-Sunni tensions was reported in the New York Times, but was not referenced in The Australian or The Age. It is of additional interest in this study that this story does not have the keyword 'terror' ${ }^{*}$ in the database subject line and did not emerge in the original search of the NYT using keywords 'Iraq' and 'terror'.

That the incident was not covered by two of Australia's leading newspapers is perhaps indicative of Iraq news being of declining importance as far as editorial decision-making goes.

In the majority of what we might call domestic 'terrorism' cases from 2012 and 2013 inside Iraq itself, the victims are Iraqis and the motivation for the killing is sectarian and political. For example, in the period of campaigning for the May 2013 Iraqi elections, voters and candidates were the intended targets. Unfortunately, a further consequence of this framing device is that Western news consumers no very little about the internal situation in Iraq today and even less about the politics of domestic Iraqi-on-Iraqi terrorism. This may have serious consequences for both public debate and policy decisions in Western nations, in relation to Iraq.

By July 2013, just three months after the 10th 'anniversary' of the 2003 invasion of Iraq, respected correspondents and senior Middle East analysts were warning that Iraq faced total collapse into sectarian civil war (McGeough, 2013). Sectarian violence, between the Sunni minority and the Shia-dominated government, claimed over 700 lives in April 2013, setting a new 'record' for civilian deaths in a month. Most deaths are caused by car bombs, armed attacks by religiouslymotivated militia and mass hangings of suspects by the State. Yet not once in McGeough's 691 word article do the words 'terror' or 'terrorism' or 'terrorist' appear; despite the fact that car bombs and death squads might be framed as terrorism in almost any other context. 
Citation: Hirst M (2013) How Relevant is the 'Terror Frame' for Discussing Media Coverage of Iraq in 2013? A Preliminary Study. J Mass Communicat Journalism 4: 168. doi:10.4172/2165-7912.1000168

This preliminary study has shown that despite a decline in the explicit framing of news from Iraq within the terror frame, acts of terrorism are continuing, if not increasing in frequency within Iraq itself. However, this is not framed as terrorism because the victims are Iraqis, not Westerners. The ideological framework in which terrorism exists for the Western media requires that the alleged terrorist action be directed at Western targets, the actions of the Iraqi regime-itself allied to the West-in targeting civilians is not considered a form of terrorism and the ongoing sectarian violence is neutralised as an issue that Western news audiences should be concerned about. I will leave the final word to Des Freedman and DayaKishanThussu:

Perhaps we have been too stunned by the images of $9 / 11$ that we focus on the spectacular and marginalize the banalities of the terror we do not, or are not allowed to, see.

\section{References}

1. Hirst M (2003) Allies down under: The Australian at war. Politics and Culture.

2. Hirst M, Patching R (2005) Journalism Ethics: Arguments and Cases. Melbourne: Oxford University Press.

3. Hirst M, Patching R (2007) Journalism ethics: arguments \& cases. (2nd edn), South Melbourne, Vic; Oxford: Oxford University Press.

4. Hirst M, Schutze R (2004) Allies Down Under? The Australian at war and the "Big Lie". In R. D. Berenger (Ed.), Global media goes to war: Role of news and entertainment media during the 2003 Iraq war Spokane, WA: Marquette Books 173-192.

5. Hirst M, Schutze R (2004) Duckspeak Crusader: Greg Sheridan's unique brand of seculo-Christian morality. Overland 176: 18-25.

6. Burke $J(2013)$ Much blood may be spilt in the sand before jihadists are defeated.

7. Gerbner G (1992) Violence and terror in and by the media. In: Raboy M, B Dagenais (1992) Media, crisis and democracy London.

8. Said E (2003) Orientalism. London: Penguin.

9. Tisdall S (2013) Was Philippines peace born in Belfast?: President meets rebels after they agree to put guns beyond use in deal inspired by the Good Friday agreement, The Guardian.

10. Gamson WA, Modigliani A (1989) Media discourse and public opinion on nuclear power: a constructionist approach. The American Journal of Sociology 95: 1-37.

11. Tiegreen S, Newman E (2008) How News is Framed. Fact Sheet.

12. lyengar S, Simon A (1993) News coverage of the Gulf crisis and public opinion: A study of agenda-setting, priming, and framing. Communication Research 20: 365-383.

13. Hallin DC (1989) The "uncensord war": The media and Vietnam. University of California Press, Berkeley, USA.

14. Hallin DC (1994) We keep America on top of the world. London. New York USA.

15. Miller D, Sabir R (2012) Propaganda and Terrorism. In: Freedman D, Thussu DK (2012) Media \& Terrorism: Global Perspectives. London.

16. Jaehnig WB (1978) Journalists and Terrorism: Captives of the Libertarian Tradition. Paper presented at the Annual Meeting of the Association for Education in Journalism, Seattle, Washington.

17. White A (2002) Journalism And The War On Terrorism: Final Report on the Aftermath of September 11 and the Implications for Journalism and Civil Liberties. Brussels: International Federation of Journalists.

\section{McMasters $P$ (2001) The war on journalism}

19. Freedman D, Thussu DK (2012) Introduction: Dynamics of media and terrorism. In: Freedmanm, Thussu DK (2012) Media \& Terrorism: Global Perspectives. London.

20. Patching R, Hirst M (2013) Journalism ethics: Arguments and cases for the twentuy-first century. London.

21. Madden J (2007) Stay course in Iraq, says Aznar. The Australian

22. Walters $P$, Dodd M (2007) PM warns against pullout from Iraq. The Australia.

23. O'Brien N (2007) Iraq-schooled jihadis a threat. The Australia.

24. The Times (2008) UK airport bomber faces life in jail, Australian, The (Australia) 7

25. Madden J, Angus T (2009) Terror quintet facing life in jail for plotting murder on a massive scale, The Weekend Australian, McMasters.

26. Cullen S, Brissenden M (2013) ASIO report: Australians fighting in Syria cause terrorism concern for spy agency. ABC News.

27. Morri M, Benns M (2013) NSW head of counter-terrorism warns of copycat attacks here after video emerges of alleged Aussie suicide bomber in Syria The Daily Telegraph

28. Iraq war's sobering legacy, a decade on (2013) The Age

29. A new Iraq, 10 years later (2013) The Australian 13.

30. Terrorism: a war without end (2013) The Age.

31. Iraq: Back to the future (2012) The Guardian.

32. Hider J (2012) Politician sentenced to death as 109 killed in wave of violence -Iraq, The Times 28.

33. Ruins of wars defy salvage efforts (2012) The Age 10.

34. Fletcher M (2013) War on Terror edging its way closer to Europe. ANALYSIS The Australian 008.

35. Source Watch (2012) Washington Institute for Near East Policy.

36. Ghazi Y, Hauser C (2013) 32 pilgrims are killed by bombings in central Iraq The New York times A8. 